\title{
TRANSLATING CULTURALLY MARKED VOCABULARY
}

\section{Palchevska O. S.}

\section{INTRODUCTION}

The problem of the relations and connections of the language, culture and ethnicity is an interdisciplinary one and the only possible way to resolve it lies in the attempt to join efforts of several sciences, including linguistics and translation. It is not new. Cultural studies are now regarded not just as an allied sector of linguistics, but as a phenomenon without the analysis of which one can not comprehend the mystery of man as well as the mystery of the language and text. And that is why the problem of translating the folk texts (folklore texts) culturally marked lexicon arises as an indispensable phenomena for understanding the source culture.

Term folklore as a notion was coined by Briton William John Thoms who, in 1846, proposed that the Anglo-Saxon compound folklore be used instead of the Latinate popular antiquities to describe "the manners, customs, observances, superstitions, ballads, proverbs" and other materials "of the olden time" ${ }^{1}$.Thus Folk texts are mainly described as the texts of the unwritten literature as expressed in folk tales, proverbs, riddles, songs, etc $^{2}$. The folk text carries the inscriptions of cultural coding in the form of myths, legends, symbols, fantasy and dreams of the source culture. The problem of understanding the folk text or (folklore text) lies in the sphere of understanding cultural identity of a certain nation. Thus the folk text carries the inscriptions of cultural coding in the form of myths, legends, symbols, fantasy and dreams of the source culture. The main problems the translator of the folklore text overcomes are generally connected with the translation of the lacunae or culturally marked lexical units.

Lacunae (culturally marked lexical units) are considered as the main difficulty for rendering from one language into another. Under lacunae vocabulary we understand lexical units that have no verbal equivalent in one of the languages being compared, due to the absence or concepts in a certain lingvoculture or lexical unit expressing this concept. The definition implies that the main lacunae vocabulary complexity is its

${ }^{1}$ McCormick Ch., White K. Folklore. An Encyclopedia of Beliefs, Customs, Tales, Music, and Art, ABC-CLIO 2010.

${ }^{2}$ Collins English Dictionary. Available online: http://www.collinsdictionary.com/dictionary/ english. 
untranslatability, which results in a process of the semantic presentation of these lexical units. Thus, in order to demonstrate the meaning of gaps, translators need to think carefully on the semantization techniques.

\section{Translation and culture}

There are lots of definitions on language which are included here shortly. Language is used to maintain and convey culture and cultural ties. Different ideas stem from differing language use within one's culture and the whole intertwining of these relationships start at one's birth. Language may refer either to the specifically human capacity for acquiring and using complex system of communication or to a specific instance of such a system of complex communication. The human language faculty is thought to be fundamentally different from and of much higher complexity than those of other species. Human language is highly complex in that it is based on a set of rules relating symbols to their meanings, thereby forming an infinite number of possible innovative utterances from a finite number of elements.

Culture is defined culture as the way of life and its manifestations that are peculiar to a community that uses a particular language as its means of expression. It is clearly stated that operationally he does not regard language as a component or feature of culture in direct opposition to the view that stated that language is part of a culture.

The term culture originally meant the cultivation of the soul or mind; culture includes behavior such as courtship or child rearing practices material things such as tools, clothing and shelter, institutions and beliefs. Culture is the sum total of the ways of living built up by a group and passed on from one generation to another. Culture is a complex whole which includes knowledge, belief, art, law, morals, customs and many other capabilities and habits acquired by man as a member of society.

The communication of the meaning of the source-language text is by means of an equivalent target-language text so translation consists of language and culture. Jerome said that two things are necessary for a good translation - an adequate understanding of the original language (source language) and an adequate command of the language into which one is translating (receptor language). Translation is a complicated process. However, a translator who is concerned with transferring the meaning will find that the receptor language has a way in which the desired meaning can be expressed, even though it may be very different from the source language form. Translation is no longer considered to be a mere crosslinguistic activity but it significantly is cross-cultural communication. 
We came to agree on the existence of the so-called "cultural universals" that enhance communication, change of ideas in order to achieve progress in all life domains. Change of ideas, concentration of mutual efforts in different directions, communication among different peoples in different ways, all these are a constant necessity of spiritual and material life. Not only cultural acts are achieved by means of continuity process alone, but also being discontinuous can be as creative at certain times. Yet, this breach is to be performed to existent models and not to a state of nothingness. But how cultures transfer through the languages? For answering this question we should consider the relationship between culture and language which is deeply rooted. Translation is the only way which does it. The fact that there is only one human species is explained by the possibility to transfer sense, meaning from one language to the other, by means of the word, thus, by translation. But during translation process there are some barriers that are discussed as follows: There are some obstacles which effect culture transferring through different languages such as limitation and censor, culture, religion, etc.

Limitation and Censor Traditionally, there is something which is lost in translation process. Limitation and censor as obstacles that limit translators in conveying the "semantic" message in the receptor language.

The other limiting factor which translators encounter is moral filtering being based on religion, family, society rules, and 84 culture, etc. Moreover limitation related to different kinds of the audience. So it is the time to say that culture itself is a filter in translation.

Culture Difficulties arising out of differences of cultures constitute the most serious problems for translators and have produced the most farreaching misunderstanding among readers.

Culture itself has its own limitation in transferring the source text into target text. Each society or group of people based on their historical background, local situations, and religion with their specific language, construct their own culture which is respected, performed and accepted along with its limitations. Limitation in translation is one of the specific features of culture, not necessarily imposed from outside world. Behaviors which are acceptable will vary from location to location.

Nowadays, the major problem in translation is being certainly influenced by different cultural norms in the source language and target language. The translator's responsibility is to choose the norms that take priority over others. It depends on translator's decision if the cultural norms of the source language, target language, or a combination of both are essential to be considered. 
Religion is one of those obstacles that cause problem in translation. Religion can be understood only by its cultural language and to translate this religious context we face with some limitations that cannot be translated. Because religious texts are described in an implicit way, natural and effective translation is almost impractical. Besides, religion and culture are interwined and religion has taken its root from human mind and soul, people accepte them by the core of their hearts. Therefore, it cannot be changed or distorted by any one. because it leads to stimulate people and evoke negative reaction by them. Therefore translators' job is more difficult and must avoid such distortion or any work which is against their religion in the process of translation.

We talked about the limitations of translation process but let's add that translation not only transfers fundamental aspects and features of culture but also it transfers modern science, and foreign histories. Therefore, that a translator's job is to eliminate and destroy boundaries is not always true. It crosses the borders to communicate cultures.

Translation plays a vital role in making a culture universal and general. It acts as a bridge to communicate all kinds of languages specially those similar to each other considering their linguistic features and cultural customs in all parts of the world. So it links all units of the world in the global network. Moreover translation presumes the existence of boundaries between different cultures and the translator most probably is aware of these boundaries and the inevitability of crossing them. Without cultural similarities and universalities, there is no way for people of different cultures to communicate with each other and translation will be impossible. When speaking of two languages which are to be translated equivalently, translators must convey the same referential, pragmatic and interlinked meanings. However, due to differences between two cultures, semantic equivalence is limited to some.

Pop culture develops within human's growth which some of those pop culture's would be a part of our life way. Since translation transfers the culture, unconsciously behind this culture, we get familiar with the pop cultures and people's habits of different regions. For example, "Mother Day" as a pop culture shows that people respect Mothers. So this special day has become a habit for all countries in different geographical regions. Also daily habits such as using the Internet have become so common globally so using this is inevitable almost for all.

Each language has its own culture and religion. Each society propagates its own specific culture through translation. Culture translation helps to know the variety of worship of different cultures. For e.g. Muslim pray in Masque, Christian in Church, Jewish in Synagogue or celebrating 
"Christmas Day" has been expanded. Thus, translation link cultures as a chain. Thus translation obviously is a cross-cultural communication; it is beyond structures and sentences, and not simply a mere language.

A proper translation makes the reader to ponder over the cultural context of the source language. Cultural borrowing is one of the advantages that transfer ideas, customs, and social behaviors from another culture. By an adequate translation readers or audience of target language culture will acquire a lot of useful benefits for e.g. hospitality; way of greeting and saying hello when they meet each other in Iran would be extend in the world through translation. The other e.g. is table manner of some nations that reflect how that nation's culture is.

The specific ways of such culturally marked lexical units translation can be reviewed through figurative categories used in folk vocabulary (metaphor, simile, connotation).

In case of translation with the absence of translation equivalents, i.e. when in the target linguvoculture the corresponding concept or linguistic sign with a similar tradition of use doesn't exist, it is practically impossible to establish the relationship between the folklore nomination and its translation equivalents. In this regard, we should speak of asymmetry and homology (a structural semantic 'resonance' between the different elements or similarity with the fundamental differences), or of a conflict "quasiequivalence" (the term Yuri Sorokin) ${ }^{3}$.

As to the translation techniques we may consider the follows:

1) the replacement of the source word (phrase) by the corresponding equivalent of the target language;

2) the interpretation, in which in addition to the equivalent in the target language translators give the information about the coincidence (or divergence) in the cultural component of meaning.

The translation of the great amount of the lacuna lexicon is frequently based on the methods of transcription / transliteration as well as by means of the semantic translation or modeling words and constructions after foreign patterns (e.g. personal, geographical names, mythological concepts so on).

This very often results in appearance of the target language words having just similar sound-graphic form, but not correlating neither to the source language notion, nor to the concept.

In case of semantic translation the lexical units of the target language are used. The problem is that such equivalents have just the close translational correspondence of meaning with the absence of conceptual content.

\footnotetext{
${ }^{3}$ Сорокин Ю.А. Переводоведение: статус переводчика и психогерменевтические прочедуры. - Москва, 2003.
} 
In this regard the main interlanguage and intercultural complications caused by the translation on micro- and macro- levels have been noted. Translation transformations aiming to overcome different kinds of complications, may either lead to the meaning loss or to semantic increments in the target text.

Lingvocultural determination of the folk units initially sets the the folk unit asymmetry in different folk traditions, reflecting the cultural identity of the mental categorization and conceptualization processes.

Language complications on the lexical level arise due to mismatch between the meanings of words, lack of semantic differentiation, different pragmatic potential of words in source and target languages, the similar notion lack or absence of interlanguage correspondences.

For example, the pragmatic potential of folklore and mythological contexts is different and the words having the equivalents in source and target languages have different associative realities: піч - сидіти на печі (stove - he would sit on the stove), пампушка - cake, стодола, клуня shed, barn, бичок - ox, піп - Роре, шинок - tavern.

For the members of the original lingvocultural community such conceptual and semantic features are typical indicators of the certain situation, but in the foreign-language and under the foreign cultural conditions they do not have these pragmatic functions: the representatives of different linguocultural community do not have the necessary presuppositions for the exact identification of these signs functions because of their non-representation in the objective world and, respectively, in folklore and mythological context. As a result, these features can be regarded as "foreign", "alien", "unclear" and, being implied in the other lingucultural space, tend to take the peripheral place.

\section{Translating culturally marked vernacular vocabulary}

Folklore, in modern usage, an academic discipline the subject matter of which (also called folklore) comprises the sum total of traditionally derived and orally or imitatively transmitted literature, material culture, and custom of subcultures within predominantly literate and technologically advanced societies; comparable study among wholly or mainly nonliterate societies belongs to the disciplines of ethnology and anthropology. In popular usage, the term folklore is sometimes restricted to the oral literature tradition.

Folklore studies began in the early 19th century. The first folklorists concentrated exclusively upon rural peasants, preferably uneducated, and a few other groups relatively untouched by modern ways (e.g., gypsies). Their aim was to trace preserved archaic customs and beliefs to their 
remote origins in order to trace the mental history of mankind. In Germany, Jacob Grimm used folklore to illuminate Germanic religion of the Dark Ages. In Britain, Sir Edward Tylor, Andrew Lang, and others combined data from anthropology and folklore to "reconstruct" the beliefs and rituals of prehistoric man. The best-known work of this type is Sir James Frazer's The Golden Bough (1890).

As the scholarship of folklore developed, an important advance was the classification of material for comparative analysis. Standards of identification were devised, notably for ballads (by F.J. Child) and for the plots and component motifs of folktales and myths (by Antti Aarne and Stith Thompson). Using these, Finnish scholars, led by Kaarle Krohn, developed the "historical-geographical" method of research, in which every known variant of a particular tale, ballad, riddle, or other item was classified as to place and date of collection in order to study distribution patterns and reconstruct "original" forms. This method, more statistical and less speculative than that of the anthropological folklorists, dominated the field throughout the first half of the 20th century.

Large collections of material were amassed in the course of these efforts. Inspired by the Grimm Brothers, whose first collection of fairy tales appeared in 1812, scholars all over Europe began recording and publishing oral literature of many genres: fairy tales and other types of folktales, ballads and other songs, oral epics, folk plays, riddles, proverbs, etc. Similar work was undertaken for music, dance, and traditional arts and crafts; many archives and museums were founded. Often the underlying impulse was nationalistic; since the folklore of a group reinforced its sense of ethnic identity, it figured prominently in many struggles for political independence and national unity ${ }^{4}$.

While dealing with the culturally marked vernacular vocabulary in different languages I came across the translations of some Ukrainian folklore texts into English: "Cossack fairy tales and folk tales by Bain R. Nisbet" "Sixty folk - tales from exclusively Slavonic sources. Translated with brief introductory notes by A. H. Wratislaw", "Myths and folk-tales of the Russians, Western Slavs, and Magyars by Jeremiah Curtin”, "Russian folktales by W. R. S. Ralston” " “The songs of the Russian people, as illustrative

${ }^{4}$ Encyclopaedia Britannica Available online www.britannica.com.

${ }^{5}$ Bain R. N. Cossack fairy tales and folk tales 1902.

${ }^{6}$ Wratislaw A. H. Sixty folk-tales from exclusively Slavonic sources. Translated with brief introductory notes by A. H. Wratisla. London 1889.

${ }^{7}$ Curtin J. Myths and folk-tales of the Russians, Western Slavs, and Magyars by Jeremiah Curtin, Boston 1903.

${ }^{8}$ Ralston W. R. S. Russian folk-tales, London 1873. 
of Slavonic mythology and Russian social life", "Songs of Ukraina with Ruthenian poems translated by Florence Randal Livesay" 10 . Those texts were chosen as the material of the following research because of the high lingvocultural potential of the folk vocabulary they contain. Our main aim was to try show the background knowledge essence in translating the cultural fragments from one language into another.

In the preface to "Cossak Fairy tales and folk-tales selected edited and translated by R. Nissbet Bain" Ukrainian is identified as the language of Cossaks: "The favorable reception given to my volume of Russian Fairy Tales has encouraged me to follow it up with a sister volume of stories selected from another Slavonic dialect extraordinarily rich in folk-tales - I mean Ruthenian, the language of the Cossacks..." Feather the translator specifies "Ruthenian is a language intermediate between Russian and Polish, but quite independent of both" ${ }^{2}$. Such argumentation is the example of the complete misidentification of the Ukraine in general as the cultural surrounding as well as of its folklore, traditional to the European folklorists, as the translations from the Ukrainian where made through Russian. As we can see, the translators as the representatives of a certain national lingvocultural communities, not always have a cognitive framework that is structured in a certain way of other national-cultural community indispensable knowledge, and this linguocultural background, specific national cultural mentality is not recognized.

Now we are going to stop on some folk text cultural codes. Being the constituents of the folklore world picture they realize the cultural asymmetry. While studying the above translations we can assume that lacuna and culturally marked vocabulary mainly deals withwith everyday life, like food and beverage, meal hours, etiquette; with living conditions, such as: living conditions in the city and in the the countryside; living standards (regional, social and ethnic group variants), chores; etiquette and ritual behavior; abstract concepts inherited by a certain culture; traditions, customs, superstitions realized in the mythology.

\footnotetext{
${ }^{9}$ Ralston W. R. S. The songs of the Russian people, as illusteative of Slavonic mythology and Russian social life, Eontton 1872.

${ }^{10}$ Livesay R. F. Songs of Ukraina with Ruthenian poems translated by Florence Randal Livesay, London 1916.

${ }^{11}$ Bain R. N. Cossack fairy tales and folk tales 1902. P. 10.

12 Ibid. P. 12.
} 


\section{Everyday life, like food and beverage, meal hours, etiquette; chores}

The folk food and beverage names are not translated but transcribed into English. Though sometimes occur the cases of mistranslation due to the attempt of the translator to substitute the specific cultural fragments with the familiar to the target language users images. We've noticed rather funny fragments with the use of traditional Ukrainian foods and beverages. For example Traditional Ukrainian spirit горілка is rendered into English by means of the lexeme brandy.

Горілка (sometimes popularly used the word горівка) (from the burning taste) or оковита (lat. Aqua vita - the water of life, living water) a strong alcoholic drink from cleaned alcohol. Горілка is made from a solution of ethanol in water, usually - 40\% (by volume). Industrially produced from high-quality cereals under alcohol purification. Beyond Ukraine the word Горілка is used to name the Ukrainian bitter pepper drink. Горілка, made at home, is called самогон оr самогонка. The main raw material for the manufacture of самогон is sugar beet or beet sugar.

Brandy, is an alcoholic beverage distilled from wine or a fermented fruit mash. The term used alone generally refers to the grape product; brandies made from the wines or fermented mashes of other fruits are commonly identified by the specific fruit name. The name comes from the Dutch brandewijn ("burnt wine"), referring to the application of heat in distillation. Commercial distillation of brandy from wine originated in the 16th century. According to one story, a Dutch shipmaster began the practice by concentrating wine for shipment, intending to add water upon reaching home port, but the concentrated beverage immediately found acceptance $^{13}$. Ukrainian folklore heroes, more often ordinary peasants, never head of brandy, as a drink.

\section{Living conditions, such as: living conditions in the city and in the the countryside; living standards (regional, social and ethnic group variants)}

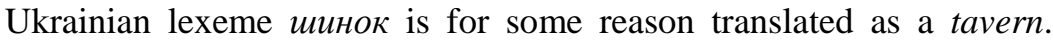
Though the nature of the words as well as their etymology is quite different. According to the Etymological Dictionary of the Ukrainian

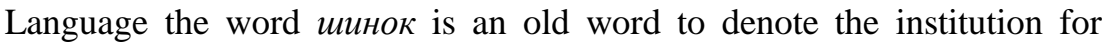
selling and drinking alcohol. The word is borrowed from Germain through Polish: g. Schenke «шинок», svl. schenk(e) «the sale of the strong drinks» connected with the word schenken «give; present wine in the korchma

\footnotetext{
${ }^{13}$ Encyclopaedia Britannica Available online www.britannica.com/
} 
(another Ukrainian name for a drinking place)», the word is close to the English skink «to pore (wine, bier)»; germ.*skankian «to hold awry» prodused from the adjective *skanka - «awry» ${ }^{14}$.

The English nomination tavern, is used to name the establishment where alcoholic beverages are sold for consumption on the premises. Tavern keeping has paralleled the growth of trade, travel, and industry throughout history and virtually worldwide (http://www.britannica.com/ topic/tavern). As to the etymology, the word tavern appeared in the late 13c., with the meaning of the "wine shop," later "public house" (mid-15c.), from Old French tavern (mid-13c.) "shed made of boards, booth, stall," also "tavern, inn," from Latin taberna "shop, inn, tavern," originally "hut, shed, rude dwelling," possibly by dissimilation from *traberna, from trabs (genitive trabis) "beam, timber," from PIE *treb"dwelling" (cognates: Lithuanian troba "a building," Old Welsh treb "house, dwelling," Welsh tref "a dwelling," Irish treb "residence," Old English ðorp "village, hamlet, farm, estate"). If so, the original meaning probably was "wooden shed"15.

\section{Traditions, customs, superstitions, mythology}

For example the Ukrainian $O x$ is transcribed as $O h$, Oh is an ancient Slavonic mythical creature, the ruler of the Forest Kingdom. Appears in the tale called "Oh" and is described as the short old man all green with a long beard. Appears out of nowhere on a stump after someone sitting on a tree stump exclaims the word "oh". In the English version of the tale $O x$ is described "as a little little old man, all so wrinkled and puckered, and his beard was quite green and reached right down to his knee”. In Ukrainian $O x$ is an exclamation used for the expression of physical pain, suffering, fear, a feeling of relief and so on. In English oh is an exclamation used to express a range of emotions including surprise, anger, disappointment, or joy, or when reacting to a remark. The target language notion is corresponding the source language word not only in the form but is very close to the base concept. But the Ukrainian word мавки is translated as water-nixies: “А за наймичок у Оха мавки - такі зелені, як рута!”. "And Oh had water-nixies for serving-maids, and they were all as green as rue." Мавка is Fairy forest creature in the image of a beautiful naked girl with long flowing hair, the closest British image is the wood nymph. The Neck, Nicor, or Nixie or Nokken (German: Nixe; Norwegian: nøkk;

${ }^{14}$ Етимологічний словник украӥнської мови в 7-ми томах Редкол. О. С. Мельничук (голов. ред.), Київ: Наукова думка 1982-1989. Т. 5, 345.

${ }^{15}$ Online Etymology Dictionary Available online: http://etymonline.com. 
Swedish: näck; Finnish:näkki) are shapeshifting water spirits in Germanic mythology and folklore, who usually appeared in forms of other creatures. Nixe from Old High German nihhus is a crocodile; related to Sanskrit nijanas "washing oneself". The male Nix (Nicker) was originally a watermonster of an animal nature, regarded as malicious and dangerous. In Sweden, it is known as Nack. The female Nixe is a water-sprite with a human torso and the tail of a fish. There are similar beings in the folklore of many nations: cf. the $\rightarrow$ Rusalka of the Slavs and the $\rightarrow$ Ningyo of the Japanese. So it is obvious that those spirits are of different nature ${ }^{16}$.

The word чopm is generally rendered by "demon" or "devil", yopm is considered to be a demon of total evil, with horns, hoofs, skinny tail, and a pig-face in Slavic mythology (demonology). He is the son of the Slavic god Chernobog and the goddess Mara. In Ukraine, he is also known as гаспид, дідько, ірод і куичий (haspyd, didko, irod, and kutsyi). In folk Christianity, he is considered a minion of Satan ${ }^{17}$.

As T. Peredriyenko observes "The feature of the nominations of the kind is that the Slavic lingvocultural name for the concept is the lexical unit yopm which is opposed to English, where the name standing for the concept is the nomination devil (Ukrainian диявол)"18. The devil is represented in church literature just as it was introduced in Slavic lingvocultures, that is devoid of national characteristics. The concept yopm has come about a very significant change: it has obtained new features, as well as managed to keep the old, absorbing the signs of the Satan and hell, pagan and Christian devil and Satan. In the modern lingvoculture the notion of чopm is used as genitive - to describe the ancient pre-Christian faith evil spirit and in the Christian sense, the image of the devil.

The direct naming of the Devil, as with the deity, has been subject to severe taboos originating in notions of word magic. There has always been respect for diabolical power and a belief that an oath invoking the Devil could be binding if heartfelt. Historically, however, the situation was more complex: the name of the Devil was very current in medieval oaths, then became euphemized, distorted, or "minced" between the Puritan and Victorian periods, and reinstated in the twentieth century. By this time, with the secularization of society, the name had little impact ${ }^{19}$.

${ }^{16}$ Online Etymology Dictionary. Available online: http://ety.monline.com.

${ }^{17}$ Войтович В. Украӥнська міфологія, Київ, 2005. С. 591.

18 Передриенко Т. Ю. Бог и дьявол Текст. Антология концептов. Т. З. Волгоград, 2006. C. 174.

${ }^{19}$ Hughes G. An encyclopedia of swearing : the social history of oaths, profanity, foul language, and ethnic slurs in the English-speaking world. Armonk: New York, 2006. P. 118. 
The English modern term devil derives from Anglo-Saxon deofol, which in turn is rooted in Greek $\delta 1 \alpha \beta 0 \lambda$ os, "the slanderer, liar or false accuser," the foundation of the notion of the Father of Lies. Although England was technically converted to Christianity in 597, Anglo-Saxon has many compounds, such as deofol craft for "witchcraft" or "devil worship," deofol seocnesse for "devil sickness" or "possession by the devil," and deofilisc, "devilish," all of which seemto be literal ${ }^{20}$.

Ukrainian Див is rendered into English by means of descriptive translation. The expression Evil Powers is used: In the olden times all manner of Evil Powers walked abroad. The translator also gives a note: Div. This ancient, untranslatable word (comp. Latin Deus)is probably of Lithuanian origin, and means any malefic power. In the Ukrainian mythology Див, Дій, Дів is first of all considered to be the God of the Sky. The ancestors usually gave the Sky the masculine image and the Land was associated with the feminine Goddesses. Див stands close to the main Slavic Gods, such as Perun, and mainly is not associated with the Evil Powers $^{21}$.

\section{Etiquette and ritual behavior}

The tradition of drinking as stereotyped behavior is one of the most common Ukrainian traditions described in the folk texts. Ukrainian expression випити на коня (to drink for the horse) is usually rendered into English as to have one for the road. In the Ukrainian correlate of this phraselogical unit we can see the updated and reinvented Cossack trip script. It refers to certain cultural stereotypes, etiquette-labeled behavior standards and, as a result, to rethinking of the original meal, drinking alcohol prototype. The origin of the English phrase to have one for the road is associated with the practice of passing death sentences. The sentenced to death was offered a last drink in the pub on the way to Tyburn Tree, the place public executions in London (http://www.backroadstouring.co.uk).

\section{Abstract concepts inherited by a certain culture}

Abstract concepts and ideas met in the Ukrainian folklore text prevail by the notions of soul (душа), happiness (щастя), fortune (доля) and so on. Ideas of the kind mainly inherit the mythologically specified images that cannot be translated in the word-to-word translation but demand the

\footnotetext{
${ }^{20}$ Hughes G. An encyclopedia of swearing : the social history of oaths, profanity, foul language, and ethnic slurs in the English-speaking world: Armonk, New York, 2006. P. 118.

${ }^{21}$ Войтович В. Українська міфологія: Київ, 2005. С. 146. 
essential knowledge of the Ukrainian specific mythology, culture as well as the folk psychology.

The peculiar feature of such concepts in Ukrainian and English is the partial difference of their semantic structure. English fortune is more abstract than Ukrainian щастя ог доля. In the English texts the word happiness mainly gives its name to the whole concept as a category: fortune acquired its meaning first in 1300, "chance, luck as a force in human affairs," from Old French fortune "lot, good fortune, misfortune" (12 c.), from Latin fortuna "chance, fate, good luck," from fors (genitive fortis) "chance, luck," possibly ultimately from PIE root*bher "to carry". If so, the sense might be "that which is brought". Sense of "owned wealth" is first found in Spenser; probably it evolved from senses of "one's condition or standing in life," hence "position as determined by wealth," then "wealth, large estate" itself. Often personified as a goddess; her wheel betokens vicissitude ${ }^{22}$.

Thus, we can say that the pursuit of happiness often met in folklore texts include, in its eessence, not only search for some abstract moral satisfaction, but also wealth. People views, specifications and superstitions concerning fortune have ethno-cultural specifications and original approach hat is differant from one civilization to another. This seme to some extent is implemented in the folklore texts. One can agree with S. G. Vorkachov who said that "the conceptual component of this concept is formed, above all, by the core definition that includes distinctive, genus-specific features that fix the boundaries of the domain to which it belongs: fortune is a positive and emotional evaluation of one's own fate. Another conceptual component formant of the fortune concept is presented by the essentialist semantics, which is associated with the interpretation of the last within a particular ideological concept. We can assume that the specific concept is precisely determined by the number of culturally marked everyday representations everyday concepts that are shared by the ethnic society members" ${ }^{23}$. So based on the following determination one can make a parallel between the English lexeme fortune, and the Ukrainian concept доля. The word доля is partially izosemic to fortune in the meaning of material wealth. According to the etymological dictionary of the Ukrainian language доля has the meaning "part; fate", and the lexemes бездолещь, бездолля, бездольний, бездольник, здольний, здольщина, знедолений, знедолити, недоля are its derivatives. The word comes from p. bl. доля, dr. доль, p. dola, ch. dola (from rus.), st. dole, slov. dol'a, дол(a) - psl. dolja "part”, connected with

\footnotetext{
${ }^{22}$ Online Etymology Dictionary. Available online .

${ }^{23}$ Воркачев С. Г. Кониепт счастья в русском языковом сознании: опыт лингвокультурологического анализа: Краснодар, 2002. С. 112.
} 
děliti "divide"; - related to lit. dalìs "part”, [dalià] "fortune, happyness", dalýti "divide"; the semantics ("part" > “доля") is close to the Russian yдел "part" - apanage; independent principality in mediaeval Russia, участь (lot, destiny) $)^{24}$.

\section{CONCLUSIONS}

It seems possible to conclude that the translation of the folk text concerning its style high frequency of outdated vocabulary and a large number of realities peculiar to a source folklore language also shows a difficulty of transferring the historical and cultural coloring. When translating it often occurs that some background cultural information, of a native speaker (source language speaker) does not correspond to the information contained in the target language. This information can turn into unfamiliar and incomprehensible, even if it deals with an ordinal, seemingly similar situation. Lacunae vocabulary, the words that can not be rendered with a simple translation, being the integral part of each of the lexical systems, depict the uniqueness of ethno-cultural group individual perception. Such vocabulary is mainly traced while dealing with everyday life, like food and beverage, meal hours, etiquette; with living conditions, such as: living conditions in the city and in the the countryside; living standards (regional, social and ethnic group variants), chores; etiquette and ritual behavior; abstract concepts inherited by a certain culture; traditions, customs, superstitions realized in the mythology. Thus the problem of rendering culturally marked lexicon in the folk text depends on the level of the translator's background knowledge. The gaps in which bring the partial or complete misunderstanding of the source text can as well lead to the full misidentification of the source language culture.

\section{SUMMARY}

The paper deals with the translation of units that belong to the folk vocabulary in Ukrainian, English taking into account specific lingvocultural features inherent in each language. The patterns of structural and semantic organization of the main translational models of such vocabulary are settled. The means of verbalization and cultural coding within "folk" world picture are traced. The conceptual basis of the linguocultural semantics objectification of folk vocabulary in Ukrainian, English texts of the XIX century are studied. Lacunae (culturally marked lexical units) are considered as the main difficulty for rendering from one

\footnotetext{
${ }^{24}$ Етимологічний словник украӥнської мови в 7-ми томах Редкол. О. С. Мельничук (голов. ред.). Київ: Наукова думка, 1982-1989. Т. 2. 107.
} 
language into another. The specific ways of such culturally marked lexical units translation are reviewed through figurative categories used in folk vocabulary (metaphor, simile, connotation). The special attention is paid to rendering the mithological lexical and phraseological units that are singled out as a separate layer of folk vocabulary, as well as the precedent phenomena impact on the appearance of precedent names. The main task of this research is to select, describe and study the folk lacunae vocabulary of the three languages in accordance to each other (based on the texts of the XIX century), to determine the means of lacunae compensation in the dictionaries as well the folk texts of the XIX centuries translated. The cause of lacunae one language units appearance in relation to the other languages and vice a versa is determined, the selection of ethnographic lacunae units are compared with other languages, as well as the development of equivalence and adequacy conditions of translation at the level of lacunae units of compared languages is studied.

\section{REFERENCES}

1. Войтович В. Українська міфологія. Київ 2005.

2. Воркачев С. Г. Конщепт счастья в русском языковом сознании: опыт лингвокультурологического анализа. Краснодар 2002.

3. Етимологічний словник украӥнської мови в 7-ми томах. Редкол.

О. С. Мельничук (голов. ред.). Київ: Наукова думка 1982-1989.

4. Передриенко Т. Ю. Бог и дьявол Текст. Антология конщептов. Т. 3. Волгоград, 2006.

5. Сорокин Ю. А. Переводоведение: статус переводчика и психогерменевтические прочедуры. Москва, 2003.

6. Bain R. N. Cossack fairy tales and folk tales 1902.

7. Collins English Dictionary. Available online: http://www.collinsdictionary.com/dictionary/english.

8. Curtin J. Myths and folk-tales of the Russians, Western Slavs, and Magyars by Jeremiah Curtin. Boston, 1903.

9. Encyclopaedia Britannica. Available online www.britannica.com.

10. Hughes G. An encyclopedia of swearing : the social history of oaths, profanity, foul language, and ethnic slurs in the English-speaking world. Armonk, New York, 2006.

11.Livesay R. F. Songs of Ukraina with Ruthenian poems translated by Florence Randal Livesay. London, 1916.

12. McCormick Ch., White K. Folklore. An Encyclopedia of Beliefs, Customs, Tales, Music, and Art. ABC-CLIO, 2010.

13. Online Etymology Dictionary. Available online http://etymonline.com.

14. Ralston W. R. S. Russian folk-tales. London, 1873. 
15. Ralston W. R. S. The songs of the Russian people, as illusteative of Slavonic mythology and Russian social life. Eontton, 1872.

16. Wratislaw A. H. Sixty folk-tales from exclusively Slavonic sources. Translated with brief introductory notes by A. H. Wratisla. London, 1889.

\section{Information about the author:}

Palchevska O. S.,

Ph.D., Associate Professor at the Department of Foreign Languages and Translation Studies,

Lviv State University of Life Safety 35, Kleparivska str., Lviv, 79007, Ukraine 